\title{
Some Recent Advances in Our Understanding of the Chemistry of Portland Cement
}

\author{
By Robert H. Bogue
}

\begin{abstract}
A review is given of some of the more important advances that have been made in our understanding of portland cement during the war years, or more specifically from 1942 to 1946 . The field covered is limited strictly to chemical research, and no attempt is made to include more than the outstanding contributions. The presentation is given of thirteen investigational fields of study, classified in four major divisions. The more significant results are brought together in a summary.
\end{abstract}

\section{Notation}

The commonly used abbreviated symbols for the cement components are used interchangeably with the conventional notation. Thus, C-CaO, S- $\mathrm{SiO}_{2}$, $\mathrm{A}-\mathrm{Al}_{2} \mathrm{O}_{3}, \quad \mathrm{~F}-\mathrm{Fe}_{2} \mathrm{O}_{2}, \quad \mathrm{H}-\mathrm{H}_{2} \mathrm{O}, \mathrm{N}-\mathrm{Na}_{2} \mathrm{O}, \mathrm{K}-\mathrm{K}_{2} \mathrm{O}, \mathrm{M}-$ $\mathrm{M}_{\mathrm{g}} \mathrm{O}$. Hence, $\mathrm{C}_{2} \mathrm{AH}_{8}-2 \mathrm{CaO} \cdot \mathrm{Al}_{2} \mathrm{O}_{3} \cdot 8 \mathrm{H}_{2} \mathrm{O}$, etc.

\section{Introduction}

Since the close of the war, scientists from countries throughout the world have been concerned with catching up on the progress made in other countries during the years when communication was barred. In our laboratories, as in others, our friends seek to learn of the advances that have come from chemical research on portland cement. The answer is not to be found in any one place. To meet that need is one of the purposes of this paper.

No attempt is made at a comprehensive picture. Only a few of the more significant studies can be presented, and these are confined to the strictly chemical fields. A more extensive treatment has recently been published elsewhere [1]. ${ }^{1}$ Many important advances likewise have been made in the fields of physics, engineering, manufacture, architecture, etc. But what we see in our own field gives promise of a most interesting future. The treatment will be directed to a review of research on phase composition, crystal structure, reactions of hydration, and new technics.

\footnotetext{
1 Figures in brackets indicate the literature references at the end of this paper.
}

\section{Phase Composition of Clinker}

Recent work upon the phase composition of portland cement clinker has given new information along several important directions.

\section{Combinations of Potash}

Although the alkalies in cement are probably never present in amounts exceeding 2 percent, and usually their total is under 1 percent, yet their presence in even smaller quantities is known to produce effects which, under certain conditions, are the subject of concern. One observed effect [12] is that increasing amounts of alkali in the mix result in increased difficulty, during manufacture, in keeping down the free $\mathrm{CaO}$. Another [36] is the undue expansion of high-alkali cements with certain types of siliceous aggregates. In order to understand the action of the alkalies in cement, it is essential to know the forms in which these elements exist in clinker, and the phase relations by which they may be controlled.

In a study of the system $\mathrm{K}_{2} \mathrm{O}-\mathrm{CaO}-\mathrm{Al}_{2} \mathrm{O}_{3}$, Brownmiller [5] found that only one compound of potash was formed which could exist in the general composition-range of portland cement. This was the binary compound KA. Taylor [39] showed later that this compound was stable in the presence of the iron compound of cement, $\mathrm{C}_{4} \mathrm{AF}$. The latter compound was known to form a solid solution with $\mathrm{C}_{2} \mathrm{~F}$ [13], and this solid solution was found to act as a pseudobinary system with the 
KA. The next step was to examine the effects resulting from the addition of the calcium silicates. This study [40] showed that $\mathrm{KA}$ reacts with $\mathrm{C}_{2} \mathrm{~S}$ and $\mathrm{C}_{3} \mathrm{~S}$ to form a potash-lime-silica compound of the composition $\mathrm{KC}_{23} \mathrm{~S}_{12}$.

Further investigation [41] revealed that the new ternary compound is stable in the presence of $\mathrm{C}_{3} \mathrm{~A}, \mathrm{C}_{4} \mathrm{AF}, \mathrm{C}_{3} \mathrm{~S}, \mathrm{C}_{2} \mathrm{~S}$ and $\mathrm{MgO}$. Hence it would be the stable potash-containing phase in the cement area of the system $\mathrm{K}_{2} \mathrm{O}-\mathrm{CaO}-\mathrm{MgO}$ $\mathrm{Al}_{2} \mathrm{O}_{3}-\mathrm{Fe}_{2} \mathrm{O}_{3}-\mathrm{SiO}_{2}$. On an exploration of the system $\mathrm{CaO}-\mathrm{KC}_{23} \mathrm{~S}_{12}-\mathrm{C}_{5} \mathrm{~A}_{3}$, a quintuple invariant point was found where $\mathrm{KC}_{23} \mathrm{~S}_{12}, \mathrm{C}_{3} \mathrm{~A}$ and $\mathrm{C}_{5} \mathrm{~A}_{3}$ are in equilibrium with liquid and vapor at $1,310^{\circ}$ C. Likewise, a quintuple point, not a eutectic, was found for the phases $\mathrm{KC}_{23} \mathrm{~S}_{12}, \mathrm{CaO}$ and $\mathrm{C}_{3} \mathrm{~A}$ at a temperature of $1,450^{\circ} \mathrm{C}$.

The discovery of the ternary potash-lime-silica compound, stable in cement systems of the above six components, explains why the addition of potash to a raw mix may result in progressively increasing amounts of free $\mathrm{CaO}$ in the clinker. Thus it may be computed that 1 percent of potash combines with 21.9 percent of $\mathrm{C}_{2} \mathrm{~S}$ to form 22.3 percent of $\mathrm{KC}_{23} \mathrm{~S}_{12}$, with the liberation of 0.6 percent of $\mathrm{CaO}$, by the equation

$$
\mathrm{K}+12 \mathrm{C}_{2} \mathrm{~S} \longrightarrow \mathrm{KC}_{23} \mathrm{~S}_{12}+\mathrm{C} \text {. }
$$

This 0.6 percent of $\mathrm{CaO}$ can combine with 1.9 percent of $\mathrm{C}_{2} \mathrm{~S}$ to form 2.5 percent of $\mathrm{C}_{3} \mathrm{~S}$ by the equation

$$
\mathrm{C}+\mathrm{C}_{2} \mathrm{~S} \longrightarrow \mathrm{C}_{3} \mathrm{~S}
$$

so that a total of 23.8 percent of $\mathrm{C}_{2} \mathrm{~S}$ will have been removed by the introduction of the 1 percent of $\mathrm{K}_{2} \mathrm{O}$. But if the mixture had a potential $\mathrm{C}_{2} \mathrm{~S}$ content less than 23.8 percent, the liberated $\mathrm{CaO}$ could not all be combined and would remain as free $\mathrm{CaO}$ in the clinker. When 1 percent of $\mathrm{K}_{2} \mathrm{O}$ reacts with $\mathrm{C}_{3} \mathrm{~S}, 29.1$ percent of the latter will be combined, with the liberation of 7.7 percent of $\mathrm{CaO}$, by the equation

$$
\mathrm{K}+12 \mathrm{C}_{3} \mathrm{~S} \longrightarrow \mathrm{KC}_{23} \mathrm{~S}_{12}+13 \mathrm{C} \text {. }
$$

Before these data could be applied directly to portland cement compositions, it was necessary to examine the effect of $\mathrm{SO}_{3}$ on the potash compound. It was found that the introduction in the raw mix of $\mathrm{SO}_{3}$ in the form of $\mathrm{CaSO}_{4}$ brought about a reaction with the $\mathrm{KC}_{23} \mathrm{~S}_{12}$ by which $\mathrm{C}_{2} \mathrm{~S}$ and $\mathrm{K}_{2} \mathrm{SO}_{4}$ were produced, in accordance with the equation

$$
\mathrm{KC}_{23} \mathrm{~S}_{12}+\mathrm{CaSO}_{4} \longrightarrow 12 \mathrm{C}_{2} \mathrm{~S}+\mathrm{K}_{2} \mathrm{SO}_{4} .
$$

Additional tests showed that, in clinker compositions, the $\mathrm{SO}_{3}$ and $\mathrm{K}_{2} \mathrm{O}$ combine preferentially as $\mathrm{K}_{2} \mathrm{SO}_{4}$, which crystallizes readily. To the extent that $\mathrm{SO}_{3}$ is available, the potash will combine with it, and only the excess of $\mathrm{K}_{2} \mathrm{O}$ will combine as $\mathrm{KC}_{23} \mathrm{~S}_{12}$. In most clinkers examined it was found that the $\mathrm{K}_{2} \mathrm{O}$ is in excess of its molecular equivalent of $\mathrm{SO}_{3}$, which would suggest the probability that the potash is present in both of the above compounds. A microscopical search for $\mathrm{K}_{2} \mathrm{SO}_{4}$ in clinkers revealed its presence in more than half of those examined. It could usually be found when the calculated potential $\mathrm{K}_{2} \mathrm{SO}_{4}$ content exceeded 0.24 percent. The existence of $\mathrm{K}_{2} \mathrm{SO}_{4}$ in clinker had previously been indicated by microscopical [4] and chemical [23] studies.

\section{Combinations of Soda}

The soda systems have been studied in much the same manner as the potash systems. It was learned [6] in 1932 that a soda compound is formed in the system $\mathrm{Na}_{2} \mathrm{O}-\mathrm{CaO}-\mathrm{Al}_{2} \mathrm{O}_{3}$, in the region of portland cement, having the composition $\mathrm{NC}_{8} \mathrm{~A}_{3}$. This compound was found to be stable in the presence of $\mathrm{C}_{3} \mathrm{~A}$, but it was necessary, as a next step, to examine its stability in the presence of the calcium silicates.

This was accomplished [11] in 1946 through the study of a portion of the quaternary system $\mathrm{Na}_{2} \mathrm{O}-\mathrm{CaO}-\mathrm{Al}_{2} \mathrm{O}_{3}-\mathrm{SiO}_{2}$, which would include the compounds $\mathrm{NC}_{8} \mathrm{~A}_{3}, \mathrm{C}_{3} \mathrm{~A}, \mathrm{C}_{3} \mathrm{~S}$ and $\mathrm{C}_{2} \mathrm{~S}$. For this purpose, a secondary system was selected within the larger system, having as components, $\mathrm{CaO}$, $\mathrm{C}_{2} \mathrm{~S}, \mathrm{NA}$ and $\mathrm{Al}_{2} \mathrm{O}_{3}$. This system, represented diagramatically as a tetrahedron, was examined by taking compositions along three planes, each of which hinged on the $\mathrm{CaO}-\mathrm{C}_{2} \mathrm{~S}$ axis, but met the $\mathrm{Al}_{2} \mathrm{O}_{3}-\mathrm{NA}$ axis at different points. These planes could then be represented as the pseudo-ternary systems,

$$
\begin{aligned}
& \mathrm{C}_{2} \mathrm{~S}-\mathrm{CaO}-\left(\mathrm{Na}_{2} \mathrm{O}+6 \mathrm{Al}_{2} \mathrm{O}_{3}\right) \\
& \mathrm{C}_{2} \mathrm{~S}-\mathrm{CaO}-\left(\mathrm{Na}_{2} \mathrm{O}+3 \mathrm{Al}_{2} \mathrm{O}_{3}\right) \\
& \mathrm{C}_{2} \mathrm{~S}-\mathrm{CaO}-\mathrm{NA}
\end{aligned}
$$

The first two planes are only arbitrary sections and do not represent true ternary systems, but the last plane is a true ternary system. In the pseudoternary systems, the compositions of liquids and crystalline phases encountered are likely to lie outside the plane, and the course of crystallization 
could not be followed from the ternary diagram. But by separate explorations in critical regions between the planes, the necessary data could be obtained.

Of especial importance, it was found that $\mathrm{NC}_{8} \mathrm{~A}_{3}$ could exist in stable equilibrium with $\mathrm{C}_{3} \mathrm{~A}$, $\mathrm{C}_{3} \mathrm{~S}$, and $\mathrm{C}_{2} \mathrm{~S}$ in the region of the system approaching portland cement in composition. An invariant point of those four crystalline compounds with liquid was found at $1,440^{\circ} \mathrm{C}$. This means that, on heating such a mixture, liquid would first appear at that temperature, and would have the determined composition of the invariant-point liquid. It appeared from microscopical and X-ray data that the $\mathrm{NC}_{8} \mathrm{~A}_{3}$ and $\mathrm{C}_{3} \mathrm{~A}$ might combine, at temperatures below that of liquid formation, to form a solid-solution series. Also, under certain conditions, it appeared that the $\mathrm{C}_{2} \mathrm{~S}$ crystallized out in the $\alpha$ rather than in the $\beta$ modification, and in that form was able to take up a small amount of soda in solid solution. But when the $\alpha \mathrm{C}_{2} \mathrm{~S}$ inverted to the $\beta$ form, the soda phase, being less soluble in the latter modification of the dicalcium silicate, came out of solution and appeared as inclusions in the $\beta \mathrm{C}_{2} \mathrm{~S}$ crystals.

It may be concluded from this study that soda may exist in a mixture of the components $\mathrm{Na}_{2} \mathrm{O}$, $\mathrm{CaO}, \mathrm{Al}_{2} \mathrm{O}_{3}$, and $\mathrm{SiO}_{2}$ in one or more of four forms:

1. As a component of glass,

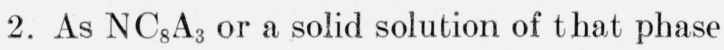
in $\mathrm{C}_{3} \mathrm{~A}$,

3. As a solid solution of a soda-bearing phase in $\alpha \mathrm{C}_{2} \mathrm{~S}$,

4. As inclusions of a soda-bearing phase in $\beta \mathrm{C}_{2} \mathrm{~S}$ produced by ex-solution on inversion of the $\alpha \mathrm{C}_{2} \mathrm{~S}$.

The amount of soda in the glass will depend on the composition and rate of cooling, and may vary in a given composition between 3.5 and 8.0 percent. The crystallization of the solid solution between $\mathrm{NC}_{8} \mathrm{~A}_{3}$ and $\mathrm{C}_{3} \mathrm{~A}$ in the form of prismatic crystals has suggested that these may explain the prismatic dark interstitial material. This phase will be discussed later. An observed enlargement of the primary-phase region of $\mathrm{CaO}$, due to the addition of $\mathrm{Na}_{2} \mathrm{O}$ to the system $\mathrm{CaO}$ $\mathrm{Al}_{2} \mathrm{O}_{3}-\mathrm{SiO}_{2}$, explains the increased difficulty of satisfactory burning with increases in the soda content of the mix.

\section{Combinations in the System $\mathrm{CaO}-\mathrm{MgO}-\mathrm{Al}_{2} \mathrm{O}_{3}-\mathrm{Fe}_{2} \mathrm{O}_{3}-\mathrm{SiO}_{2}$}

In a recent paper by Swayze [38], three systems of immediate interest to an understanding of portland cement constitution have been reported. These are:

(a) $\mathrm{CaO}-\mathrm{C}_{5} \mathrm{~A}_{3}-\mathrm{C}_{2} \mathrm{~F}$,

(b) $\mathrm{CaO}-\mathrm{C}_{5} \mathrm{~A}_{3}-\mathrm{C}_{2} \mathrm{~F}-\mathrm{C}_{2} \mathrm{~S}$, and

(c) $\mathrm{CaO}-\mathrm{C}_{5} \mathrm{~A}_{3}-\mathrm{C}_{2} \mathrm{~F}-\mathrm{C}_{2} \mathrm{~S}$ plus 5 percent of $\mathrm{MgO}$.

These will be considered separately.

\section{(a) System $\mathrm{CaO}-\mathrm{C}_{5} \mathrm{~A}_{3}-\mathrm{C}_{2} \mathrm{~F}$}

In mixtures containing ferric oxide, difficulty has usually been experienced in obtaining satisfactory quenched charges due to the very rapid crystallization of the iron compounds. Swayze overcame this difficulty by using very small charges (0.002 to $0.015 \mathrm{~g}$ ), placing these on open, concave platinum-foil containers, and quenching in water. By this means, charges containing up to 75 percent $\mathrm{C}_{4} \mathrm{AF}$ could be completely frozen as glass.

It had been reported formerly [13] that $\mathrm{C}_{2} \mathrm{~F}$ forms a solid-solution series with a hypothetical $\mathrm{C}_{2} \mathrm{~A}$ up to a composition of $\mathrm{C}_{4} \mathrm{AF}$. As this was the end member of the series highest in alumina, and as cements nearly always contain alumina in excess of the amount that could thus combine with the available ferric oxide, the compound $\mathrm{C}_{4} \mathrm{AF}$ was considered to be the stable iron-containing compound of portland cement. Swayze found, however, that the solid-solution series extends further towards the $\mathrm{C}_{2} \mathrm{~A}$ point, reaching an end member having the composition $\mathrm{C}_{6} \mathrm{~A}_{2} \mathrm{~F}$. The $\mathrm{Al}_{2} \mathrm{O}_{3}: \mathrm{Fe}_{2} \mathrm{O}_{3}$ ration of $\mathrm{C}_{6} \mathrm{~A}_{2} \mathrm{~F}$ is 1.28 whereas that of $\mathrm{C}_{4} \mathrm{AF}$ is 0.64. This means, therefore, that in portland cements having an $\mathrm{Al}_{2} \mathrm{O}_{3}: \mathrm{Fe}_{2} \mathrm{O}_{3}$ ratio above 1.28 the iron will be present (at crystalline equilibrium) in the form of $\mathrm{C}_{6} \mathrm{~A}_{2} \mathrm{~F}$. And in cements having an $\mathrm{Al}_{2} \mathrm{O}_{3}: \mathrm{Fe}_{2} \mathrm{O}_{3}$ ratio between 1.28 and 0.64 , the composition of the crystalline iron phase will have a composition between that of $\mathrm{C}_{6} \mathrm{~A}_{2} \mathrm{~F}$ and $\mathrm{C}_{4} \mathrm{AF}$. If the $\mathrm{Al}_{2} \mathrm{O}_{3}: \mathrm{Fe}_{2} \mathrm{O}_{3}$ ratio is below 0.64 , the composition of the iron phase will lie between that of $\mathrm{C}_{4} \mathrm{AF}$ and $\mathrm{C}_{2} \mathrm{~F}$. According to the earlier studies, $\mathrm{C}_{3} \mathrm{~A}$ could appear as a separate phase from compositions having an $\mathrm{Al}_{2} \mathrm{O}_{3}: \mathrm{Fe}_{2} \mathrm{O}_{3}$ ratio in excess of 0.64 , but from the new work this appears not to be possible until that ratio has exceeded 1.28. 


\section{(b) System $\mathrm{CaO}-\mathrm{C}_{5} \mathrm{~A}_{3}-\mathrm{C}_{2} \mathrm{~F}-\mathrm{C}_{2} \mathrm{~S}$}

The above study on the ternary system was extended into the quaternary system with silica by addition of the fourth component, $\mathrm{C}_{2} \mathrm{~S}$. This was necessary in order to find the influence of the above phase relations on the formation of the calcium silicates. This system previously had been reported by Lea and Parker [26].

The principal interest here is concerned with the $\mathrm{C}_{3} \mathrm{~S}$ area and the invariant points of that phase with those adjacent to it. The work of Swayze shows excellent agreement with the earlier work in the temperatures of the invariant points $\mathrm{CaO}-\mathrm{C}_{3} \mathrm{~S}-\mathrm{C}_{3} \mathrm{~A}$-iron phase and $\mathrm{C}_{3} \mathrm{~S}-\mathrm{C}_{2} \mathrm{~S}-$ $\mathrm{C}_{3} \mathrm{~A}$-iron phase. His compositions, however, are richer in iron and poorer in lime than the corresponding points of Lea and Parker. This appears to be of especial significance by bringing these invariant compositions outside the tetrahedron $\mathrm{C}_{3} \mathrm{~S}-\mathrm{C}_{2} \mathrm{~S}-\mathrm{C}_{3} \mathrm{~A}-\mathrm{C}_{6} \mathrm{~A}_{2} \mathrm{~F}$. This indicates that the iron phase that will be in equilibrium in the final products of crystallization of those compositions will belong to the solid-solution series.

\section{(c) System $\mathrm{CaO}-\mathrm{C}_{5} \mathrm{~A}_{3}-\mathrm{C}_{2} \mathrm{~F}-\mathrm{C}_{2} \mathrm{~S}$ Plus 5 Percent $\mathrm{MgO}$}

As all portland-cement clinkers contain some magnesia, the study was continued with the introduction of 5 percent of $\mathrm{MgO}$. This amount was added because it previously had been learned that liquids in the region under study, between $\mathrm{Al}_{2} \mathrm{O}_{3}: \mathrm{Fe}_{2} \mathrm{O}_{3}$ ratios of 1.35 and 1.60 , take up slightly less than 5 percent of $\mathrm{MgO}$ at temperatures at which the $\mathrm{C}_{3} \mathrm{~A}$ and the iron phase have just disappeared. Saturation of the liquid was indicated by the presence of small amounts of periclase $(\mathrm{MgO})$ in most of the glasses examined.

The effect due to the introduction of the $\mathrm{MgO}$ was found to be an increase of the $\mathrm{Al}_{2} \mathrm{O}_{3}$ content and a decrease in $\mathrm{Fe}_{2} \mathrm{O}_{3}$ and $\mathrm{CaO}$, in both of the principal invariant compositions. This lengthens the field of the iron solid-solution phase and shortens that of the $\mathrm{C}_{3} \mathrm{~A}$ on the $\mathrm{C}_{3} \mathrm{~S}$ surface to such an extent that the invariant points are brought to the high-alumina side of the plane that passes through $\mathrm{C}_{3} \mathrm{~S}, \mathrm{C}_{2} \mathrm{~S}$ and $\mathrm{C}_{6} \mathrm{~A}_{2} \mathrm{~F}$. This brings these points within the tetrahedron $\mathrm{C}_{3} \mathrm{~S}-\mathrm{C}_{2} \mathrm{~S}-$ $\mathrm{C}_{3} \mathrm{~A}-\mathrm{C}_{6} \mathrm{~A}_{2} \mathrm{~F}$, and makes possible the formation of $\mathrm{C}_{6} \mathrm{~A}_{2} \mathrm{~F}$ in the presence of $\mathrm{C}_{3} \mathrm{~A}, \mathrm{C}_{2} \mathrm{~S}$ and liquid.

In these studies, it was shown that crystals of one phase might become embedded in another phase during crystallization of the latter and so prevent the theoretical course of crystallization, even at very slow cooling. Thus $\mathrm{CaO}$, which under theoretical equilibrium would be resorbed, may be left free, enclosed in crystals of $\mathrm{C}_{3} \mathrm{~A}$ or $\mathrm{C}_{3} \mathrm{~S}$. Furthermore, as the members of the solidsolution series are stable in the presence of each other, there may be practically no redistribution of $\mathrm{Fe}_{2} \mathrm{O}_{3}$ and $\mathrm{Al}_{2} \mathrm{O}_{3}$ within the growing crystals, which would be necessary under equilibrium cooling. This makes possible the formation of crystals having a low $\mathrm{Al}_{2} \mathrm{O}_{3}: \mathrm{Fe}_{2} \mathrm{O}_{3}$ ratio core and a higher $\mathrm{Al}_{2} \mathrm{O}_{3}: \mathrm{Fe}_{2} \mathrm{O}_{3}$ ratio exterior.

Swayze points out that the establishment of a solid-solution series ranging from $\mathrm{C}_{2} \mathrm{~F}$ to $\mathrm{C}_{6} \mathrm{~A}_{2} \mathrm{~F}$ may explain many anomalies that have been observed in the constitution of portland cement. Thus the petrographic examination of clinkers has usually shown an excess of $\mathrm{C}_{3} \mathrm{~S}$ and a deficiency of $\mathrm{C}_{2} \mathrm{~S}$ and $\mathrm{C}_{3} \mathrm{~A}$ from the amounts calculated on the assumption that the iron is completely in the form of $\mathrm{C}_{4} \mathrm{AF}$. If the iron goes into combination as $\mathrm{C}_{6} \mathrm{~A}_{2} \mathrm{~F}$, more $\mathrm{Al}_{2} \mathrm{O}_{3}$ is taken into that compound, and less into $\mathrm{C}_{3} \mathrm{~A}$. This leaves an excess of $\mathrm{CaO}$ to combine with $\mathrm{C}_{2} \mathrm{~S}$, reducing the latter and increasing the $\mathrm{C}_{3} \mathrm{~S}$. Likewise, the heat of solution of $\mathrm{C}_{6} \mathrm{~A}_{2} \mathrm{~F}$ may be expected to differ from that of $\mathrm{C}_{4} \mathrm{AF}$, and this would affect the calculated values for glass content as obtained by heat-of-solution methods.

Before closing this section of the paper, attention should be called to a recent contribution by Dahl [8] in which the interpretation of phase diagrams is considered. Of especial interest in connection with phase-equilibria studies on portland cement, methods are developed for determining the phases present at equilibrium at any given temperature, and for estimating their proportions, without tracing the course of crystallization from the liquid state. Attention is also given to the role of the liquid phase in the processes of fusion and crystallization, as a means of gaining an understanding of the mechanism by which the oxides in the raw materials are transformed into the various cement compounds.

\section{Prismatic Tricalcium Aluminate}

When polished and etched sections of clinkers are examined under the metallurgical microscope, there is often observed a dark interstitial material. This may occur in three forms. A rectangular 
phase has been identified as $3 \mathrm{CaO} \cdot \mathrm{Al}_{2} \mathrm{O}_{3}$, and an amorphous phase as glass [20]. A prismatic phase has been observed in many clinkers [19] but, when charges have been made from pure materials, only those containing $\mathrm{K}_{2} \mathrm{O}$ or $\mathrm{Na}_{2} \mathrm{O}$ have shown that phase. The optical properties of the prismatic phase, however, did not correspond with those of any of the known alkali compounds, nor has there been revealed any relationship between the percentage of alkalies in clinker and the amount of prismatic material observed [43]. There was seen, however, to be a close relationship between the total dark interstitial material and the potential $\mathrm{C}_{3} \mathrm{~A}$ content. The prismatic phase was found to be more abundant in clinkers that were cooled at an intermediate rate: when rapidly cooled, glass predominated, and when slowly cooled, the rectangular form predominated.

In a study looking to the solution of the problem, Taylor [42] selected a number of compositions in the system $\mathrm{KC}_{23} \mathrm{~S}_{12}-\mathrm{CaO}-\mathrm{C}_{5} \mathrm{~A}_{3}$, and subjected them to a variety of heat treatments. The results of this study showed that, under equilibrium cooling, the prismatic form was not observed in any case. Under more rapid cooling the prismatic form appeared in those compositions in which $\mathrm{C}_{3} \mathrm{~A}$ was one of the compounds anticipated from the phase diagram [41]. If the charge were quenched from a temperature above that at which $\mathrm{C}_{3} \mathrm{~A}$ was formed, the prismatic phase was not found.

This study indicated that $\mathrm{C}_{3} \mathrm{~A}$ may separate from a mixture in three forms. When quenched above the temperature of crystallization, it will be glass, observed as an amorphous dark interstitia] phase. When cooled slowly enough to attain equilibrium crystallization, it will appear as rectangular crystals. But when cooled at intermediate rates, it may separate in prismatic form. No methods appeared to be available for defining precisely the composition of that phase but, if it is a solid solution, the extent of such solution was shown to be very slight. The presence of $\mathrm{K}_{2} \mathrm{O}$ and $\mathrm{SiO}_{2}$ or $\mathrm{Na}_{2} \mathrm{O}$ and $\mathrm{SiO}_{2}$ appears to be essential to its formation, but the reason assigned is associated with the attainment in the crystallizing liquid of the proper environment for the production of a metastable phase.

From this study it is concluded that the prismatic dark interstitial material is a metastable form of tricalcium aluminate, monotropic with respect to the stable, isotropic, rectangular form of that compound.

\section{Inversion of Dicalcium Silicate}

The inversion temperature of $\alpha$ to $\beta \mathrm{C}_{2} \mathrm{~S}$ was reported in 1915 by Rankin and Wright [34] as $1420^{\circ} \pm 2^{\circ}$ C. In a study by Newman and Wells [32] on the effect of added materials on $\mathrm{C}_{2} \mathrm{~S}$, the authors observed inconsistencies in heating- and cooling-curves that denoted that the earlier inversion-temperature value had been set too low. By the use of differential heatingcurves, the points of energy-change could be established with a high degree of precision.

A standard sample of $\gamma \mathrm{C}_{2} \mathrm{~S}$ was prepared from "low alkali" $\mathrm{CaCO}_{3}$ (containing less than 0.042 percent total determined impurities), and a silica gel $(0.06$ percent residue nonvolatile with $\mathrm{HF})$. A precisely proportioned mixture was heated for 1 hour at $1450^{\circ} \mathrm{C}$, cooled, remixed, and the process repeated three times. A $\beta-\alpha$ inversion temperature of $1456^{\circ} \pm 2.2^{\circ} \mathrm{C}$ was obtained.

The addition of $\mathrm{CaO}$ up to 4 percent did not change the $\beta-\alpha$ inversion temperature, nor did the addition of 0.12 percent of $\mathrm{SiO}_{2}$. But when 0.19 percent of $\mathrm{SiO}_{2}$ was added, the inversion temperature was lowered to $1,438^{\circ} \mathrm{C}$. Further additions of $\mathrm{SiO}_{2}$ caused no further reductions. As these small variations in composition could not readily be detected by chemical means, the authors concluded that the inversion temperature of pure dicalcium silicate could be assumed to be $1,438^{\circ} \mathrm{C}$ (which would be raised to $1,456^{\circ} \mathrm{C}$ by the addition of a small amount of $\mathrm{CaO}$ ), or $1,456^{\circ} \mathrm{C}$ (which would be lowered to $1,438^{\circ} \mathrm{C}$ by the addition of a small amount of $\mathrm{SiO}_{2}$ ). The authors believe that the higher value more cor. rectly indicates the true inversion temperature.

The authors then studied the effects due to the introduction of foreign oxides. The principle was followed that the inversion temperature is lowered when a foreign material is less soluble in the lowtemperature form (as $\beta \mathrm{C}_{2} \mathrm{~S}$ ) than in the hightemperature form (as $\alpha \mathrm{C}_{2} \mathrm{~S}$ ). After saturation is reached, no further temperature change takes place. Hence, by plotting inversion temperature against increasing concentration of solute added, the limiting solubility is noted as the concentration beyond which the inversion temperature remains sensibly constant. The solubilities of the mate- 
rials added to $\mathrm{C}_{2} \mathrm{~S}$ and the corresponding lowerings in the inversion temperature, were reported and found to vary over a wide range, as shown in table 1 .

TABLE 1.-Solubility of oxides in $\alpha \mathrm{C}_{2} \mathrm{~S}$, and consequent lowerings in inversion temperature

\begin{tabular}{|c|c|c|}
\hline Oxide & $\begin{array}{l}\text { Solubility } \\
\text { in } \mathrm{C}_{2} \mathrm{~S}\end{array}$ & $\begin{array}{c}\text { Lowering in } \\
\text { temperature } \\
\text { of inversion } \\
\text { point }\end{array}$ \\
\hline & & $\circ \mathrm{C}$ \\
\hline $\mathrm{Al}_{2} \mathrm{O}_{3}$ & 0.5 & 14 \\
\hline $\mathrm{MgO}$ & .5 & 20 \\
\hline $\mathrm{Fe}_{2} \mathrm{O}_{3}$ & 1.0 & 20 \\
\hline $\mathrm{CaF}_{2} \ldots$ & .7 & 2 \\
\hline $\mathrm{TiO}_{2 .}$ & 1.0 & 21 \\
\hline $\mathrm{BaO} \ldots$ & ${ }^{1} 20$ & 200 \\
\hline $\mathrm{Cr}_{2} \mathrm{O}_{3 \ldots}$ & 2.5 & 61 \\
\hline $\mathrm{V}_{2} \mathrm{O}_{5} \ldots \ldots$ & .5 & 29 \\
\hline $\mathrm{P}_{2} \mathrm{O}_{5} \ldots$ & 1.0 & 66 \\
\hline $\mathrm{B}_{2} \mathrm{O}_{3} \ldots$ & 8.0 & 151 \\
\hline $\mathrm{Mn}_{2} \mathrm{O}_{3} \ldots \ldots$ & 8.0 & 73 \\
\hline $\mathrm{K}_{2} \mathrm{O}$ & 1. 6 & 54 \\
\hline $\mathrm{Na}_{2} \mathrm{O}$ & ${ }^{1} 1.3$ & 166 \\
\hline
\end{tabular}

${ }^{1}$ Limit not reached.

A study of the $\beta$ to $\gamma$ inversion of $\mathrm{C}_{2} \mathrm{~S}$ has been made by Zerfoss and Davis [46]. The effects were observed of the addition of oxides of $\mathrm{P}, \mathrm{As}$, $\mathrm{Sb}, \mathrm{V}, \mathrm{Ba}, \mathrm{Sr}, \mathrm{Zn}, \mathrm{Cr}, \mathrm{W}, \mathrm{Mo}$ and Ti. These investigators found that the addition of 1 mole percent of $\mathrm{P}_{2} \mathrm{O}_{5}, \mathrm{As}_{2} \mathrm{O}_{5}, \mathrm{~V}_{2} \mathrm{O}_{5}$, or $\mathrm{Cr}_{2} \mathrm{O}_{3}$ inhibited the inversion and allowed the $\beta \mathrm{C}_{2} \mathrm{~S}$ to be stable at room temperatures. It had long been known that $\mathrm{B}_{2} \mathrm{O}_{3}$ prevented dusting, and recent work by Newman and Wells [32] has shown that $\mathrm{Mn}_{2} \mathrm{O}_{3}$ likewise should be included.

In all cases, the optical properties of the $\mathrm{C}_{2} \mathrm{~S}$ were changed, which indicates the formation of a solid solution. Zerfoss and Davis conclude that the $\beta-\gamma$ inversion can be inhibited in two ways: chemically through the formation of a solid solution, and physically through the restraining influence of surrounding phases. The solid solution does not invert because of the high energy requirement necessary to force out the dissolved ion and allow the silicate to assume the stable form. In physical inhibition, the surrounding phases restrain the beta form from expanding to the gamma form, and isolate the grains so as to disturb and block the inversion wave.

According to these authors, the inversion involves an increase in the coordination number of the calcium, and any means by which the low coordination of the calcium in $\beta \mathrm{C}_{2} \mathrm{~S}$ can be pre- served will prevent inversion. Thus they argue that we may consider the operation of the inversion as a stage in the competition of calcium and silicon for oxygen. Hence, by inserting other highly-charged atoms into the silicate structure, they, with the silicon, will compete with the calcium for the oxygen and will assist in preserving the low coordination of the calcium.

\section{Crystal Structure}

A few studies on the crystal structure of the cement compounds during the past five-year period are of particular interest.

\section{Structure of Tricalcium Aluminate}

The structure of $\mathrm{C}_{3} \mathrm{~A}$ has been examined by a number of investigators. From studies of X-ray diffraction patterns, Harrington [14] concluded that it was "pseudocubic" with a unit cell having $a_{0}=7.62 \mathrm{~A}$. There were however a number of lines to which he was unable to assign cubic indices. The density indicated three molecules in the cell. Steele and Davey [37] reported that the cell was cubic, with $a_{0}=7.64 \mathrm{~A}$. There were difficulties however in the suggested arrangements of the atoms. Lagerquist, Wallmark and Westgren [25] assigned to the compound a cubic cell with an edge of $15.22 \mathrm{~A}$, which would give 24 molecules per unit cell.

Data obtained by McMurdie [29] indicate a cubic unit cell with $a_{0}=15.24 \mathrm{~A}$, which allow all of the observed lines to be indexed. The strong lines of the diffraction pattern are those of a bodycentered cube, with $a_{0}=3.81 \mathrm{~A}$, which were shown to be caused by an arrangement of metal atoms at or near the corners of $3.81 \mathrm{~A}$ cubes. By comparison with the known structure of other compounds having similar lines, it was shown that no deductions were permissible concerning the arrangement of the oxygen atoms. It had previously been noted by Brownmiller [5] that X-ray diffraction patterns consisting of the strong lines of $\mathrm{C}_{3} \mathrm{~A}$ were obtained from various quickly cooled liquids in the area of portland cement, even from some compositions in which $\mathrm{Al}_{2} \mathrm{O}_{3}$ was not present. His explanation was that this material was a metastable phase which, on slower cooling, was transformed to the stable crystalline phases. McMurdie concluded from his studies that the pattern was due to submicroscopic quench growths of a metastable crystalline compound. 


\section{Structure of Dicalcium Silicate}

An important series of studies has been reported by Bredig [3] that have clarified the crystal structure of the several forms of dicalcium silicate. A group of compounds (as $\mathrm{K}_{2} \mathrm{SO}_{4}, \mathrm{Na}_{2} \mathrm{SO}_{4}, \mathrm{CaNaPO}$, $\mathrm{CaKPO}_{4}$ ) is represented by the general formula $\mathrm{A}_{2} \mathrm{XO}_{4}$. Although occurring in more than one modification, their high-temperature $(\alpha)$ forms are similar and show hexagonal symmetry. Bredig observed, however, that a number of other phases, formerly designated as compounds, showed this same crystal symmetry. Thus glaserite $\mathrm{K}_{3} \mathrm{Na}$ $\left(\mathrm{SO}_{4}\right)_{2}$, and the silica-phosphate $7 \mathrm{CaO} \cdot \mathrm{P}_{2} \mathrm{O}_{5} \cdot 2 \mathrm{SiO}_{2}$ gave the simple crystal lattice of the $\alpha \mathrm{A}_{2} \mathrm{XO}_{4}$ group. For this reason they are believed by Bredig to be solid solutions. In the first case, the solution would be of $\mathrm{Na}_{2} \mathrm{SO}_{4}$ in $\mathrm{K}_{2} \mathrm{SO}_{4}$; in the latter case, of $3 \mathrm{CaO} . \mathrm{P}_{2} \mathrm{O}_{5}$ in $2 \mathrm{CaO} . \mathrm{SiO}_{2}$.

A similar structure obtained by Greene [10] with specially heat-treated mixtures of $\mathrm{Na}_{2} \mathrm{O}$ and $\mathrm{Fe}_{2} \mathrm{O}_{3}$, or $\mathrm{Na}_{2} \mathrm{O}$ and $\mathrm{Al}_{2} \mathrm{O}_{3}$, with $\mathrm{C}_{2} \mathrm{~S}$ led him to conclude that solid solutions had been formed of $\mathrm{Na}_{2} \mathrm{O}$, with $\mathrm{Fe}_{2} \mathrm{O}_{3}$ or $\mathrm{Al}_{2} \mathrm{O}_{3}$, in $\mathrm{C}_{2} \mathrm{~S}$. The structure in both of these cases was that of the $\alpha \mathrm{A}_{2} \mathrm{XO}_{4}$ group, which is offered as evidence that the $\mathrm{C}_{2} \mathrm{~S}$ in these preparations is in the $\alpha$ form. The conclusion of this study was that $\alpha \mathrm{C}_{2} \mathrm{~S}$ has a hexagonal symmetry and is stable at some high temperature; that ordinarily it is impossible to prevent inversions during cooling, but that the presence of substances in solid solution may cause the $\alpha$ form to be retained at room temperatures. A slow cooling through the transition-temperature range, however, brings about the inversion, as noted by a change in symmetry and the appearance of the typically-twinned $\beta$ form.

Furthermore, it appears that the components of the solid solution are less soluble in the $\beta$ than in the $\alpha$ form of $\mathrm{C}_{2} \mathrm{~S}$, and so separate during the inversion. This gives rise to the inclusions commonly observed in the $\mathrm{C}_{2} \mathrm{~S}$ crystals of commercial clinkers. Greene found the inversion temperature to be lowered by the solution: to $1,175^{\circ}$ by the $\mathrm{Na}_{2} \mathrm{O}+\mathrm{Fe}_{2} \mathrm{O}_{3}$, and to $1,180^{\circ}$ by the $\mathrm{Na}_{2} \mathrm{O}+\mathrm{Al}_{2} \mathrm{O}_{3}$. These results led to the conclusion that the crystals formerly described as $\alpha \mathrm{C}_{2} \mathrm{~S}$ were in reality the $\beta$ modification, the slight differences observed being due to solid solutions.

By a similar procedure, Bredig showed that the phases $27 \mathrm{CaO} . \mathrm{P}_{2} \mathrm{O}_{5} .12 \mathrm{SiO}_{2}$ and $\mathrm{K}_{2} \mathrm{O} .23 \mathrm{CaO} .12 \mathrm{SiO}_{2}$, which had been considered as compounds, have a structure corresponding to the $\beta$ or low-temperature form of $\mathrm{K}_{2} \mathrm{SO}_{4}$. This indicates to Bredig that those compounds are solid solutions, the former of $3 \mathrm{CaO} \cdot \mathrm{P}_{2} \mathrm{O}_{5}$ and the latter of $\mathrm{K}_{2} \mathrm{O} \cdot \mathrm{CaO} \cdot \mathrm{SiO}_{2}$ in $2 \mathrm{CaO} . \mathrm{SiO}_{2}$. The symmetry of this hypothetical form of $\mathrm{C}_{2} \mathrm{~S}$ is lower than that of the $\alpha$ form but higher than that of $\beta \mathrm{C}_{2} \mathrm{~S}$. Since these solid solutions have the structure of $\beta \mathrm{K}_{2} \mathrm{SO}_{4}$, it is assumed that pure $\mathrm{C}_{2} \mathrm{~S}$ must also possess this structure in some temperature range. This new form is designated by Bredig as $\alpha^{\prime} \mathrm{C}_{2} \mathrm{~S}$. Its temperature of stability is believed to be immediately above the $\alpha^{\prime}-\beta$ transition point $\left(1,420^{\circ} \mathrm{C}\right.$ according to Rankin and Wright, and $1,456^{\circ} \mathrm{C}$ according to Newman and Wells, see above), and that of $\alpha \mathrm{C}_{2} \mathrm{~S}$ to range from the $\alpha-\alpha^{\prime}$ transition point (undetermined) up to the melting point of $\mathrm{C}_{2} \mathrm{~S}$.

The work of Bredig led to further developments on the relative activities of the various forms of dicalcium silicate. Brandenberger [2] had advanced the theory that the calcium ion at room temperature tends to surround itself with more oxygen ions than at high temperatures. Thus the coordination number of $\mathrm{Ca}$ for $\mathrm{O}$ in $\gamma \mathrm{C}_{2} \mathrm{~S}$ is believed to be 6 , but for the $\beta \mathrm{C}_{2} \mathrm{~S}$, stable at higher temperatures, it is considered to be less than that value, and is set at 4 . If this is true, an increased activity results upon a decrease in coordination number of $\mathrm{CaO}_{6}$ to $\mathrm{CaO}_{4}$. This theory was advanced on the premise that, with rising temperatures, the $\mathrm{Ca}$ ions exert a loosening influence upon the state of polarization of the $\mathrm{O}$ ions, increasing the distance between them and the $\mathrm{Si}$ ions, and so diminishing the bond between them. Such action was called "contrapolarization."

Bredig argues against the possibility of this effect with rising temperature. On the contrary, he contends that it is at low heat contents that the weaker $\mathrm{Ca}$ cation may approach the $\mathrm{SiO}_{2}$ radical close enough to exert increased attraction upon the electron shell of the $\mathrm{O}$ ions, and be able thereby to repulse the Si ions. Hence, he argues, if the coordination number of $\mathrm{Ca}$ for $\mathrm{O}$ in $\gamma \mathrm{C}_{2} \mathrm{~S}$ is 6 , as there is reason to believe, the number will increase in the polymorphic forms stable at the higher temperatures. He places the value in the $\alpha$ and $\alpha^{\prime}$ forms at about 10 , and in the $\beta$ form at an intermediate value, probably 8 .

In justification for this assumption, Bredig 
points out that, in $\mathrm{Ca}(\mathrm{OH})_{2}$, the $\mathrm{Ca}$ ion establishes around itself a shell of 6 oxygen ions. In $\gamma \mathrm{C}_{2} \mathrm{~S}$, where the shell already consists of $\mathrm{CaO}_{6}$, there is no potential to afford the chemical exchange in reaction with water. Hence $\gamma \mathrm{C}_{2} \mathrm{~S}$ is unreactive towards water. But in the case of the unstable coordination $\mathrm{CaO}_{8}$ of the $\beta \mathrm{C}_{2} \mathrm{~S}$, the tendency to revert to $\mathrm{CaO}_{6}$ may be so great that the change in free energy may account for the activation energy of interaction with water.

The assumption of a hexagonal form of $\mathrm{C}_{2} \mathrm{~S}$, stable at a temperature above the transition temperature, has recently been confirmed by McMurdie and van Valkenburg [31]. Making use of a specially-designed furnace, in connection with a Phillips X-ray spectrometer (which employs a Geiger counter in place of a photographic film), the diffraction pattern was obtained on a specimen at about $1,500^{\circ} \mathrm{C}$, and the hexagonal structure noted.

\section{Reactions of Hydration}

In the field of the hydration of the cement compounds, important advances have currently been made along several directions.

\section{System $\mathrm{CaO}-\mathrm{Al}_{2} \mathrm{O}_{3}-\mathrm{H}_{2} \mathrm{O}$}

A recent study of much interest has been made by Wells, Clarke, and McMurdie [44] on the system $\mathrm{CaO}-\mathrm{Al}_{2} \mathrm{O}_{3}-\mathrm{H}_{2} \mathrm{O}$ at $21^{\circ}$ and at $90^{\circ} \mathrm{C}$. Metastable solutions of calcium aluminates were prepared by shaking for an hour or so either anhydrous calcium aluminates less basic than $\mathrm{C}_{3} \mathrm{~A}$, or alkali-free calcium aluminate cements, with distilled water in the proportion of $50 \mathrm{~g}$ per liter. These mixtures were filtered, and clear solutions obtained containing up to $2.4 \mathrm{~g}$ of $\mathrm{Al}_{2} \mathrm{O}_{3}$ and $1.4 \mathrm{~g}$ of $\mathrm{CaO}$ per liter. Portions were then mixed with solutions of $\mathrm{Ca}(\mathrm{OH})_{2}$ of known concentrations and the changes in the solution observed.

It was noted that increases in $\mathrm{CaO}$ content of the solutions were accompanied by decreases in $\mathrm{A}_{2} \mathrm{O}_{3}$ content, and a gradual increase from 2 to 4 in the molar ratio $\mathrm{CaO}: \mathrm{Al}_{2} \mathrm{O}_{3}$ in the solid phases. This latter effect could be due either to an overlapping of the solubility curves of a series of separate hydrated aluminates, or to the solubility curve of a solid-solution series of varying $\mathrm{CaO}$. $\mathrm{A}_{2} \mathrm{O}_{3}$ ratio. The problem could not be solved by the examination of the optical properties of the crystals, because the individual crystals were too small for satisfactory interference figures. Refractive indices were not greatly different between crystals of low lime content $\left(2 \mathrm{CaO} . \mathrm{Al}_{2} \mathrm{O}_{3} .5-9 \mathrm{H}_{2} \mathrm{O}\right)$ and those of high lime content $\left(4 \mathrm{CaO} . \mathrm{Al}_{2} \mathrm{O}_{3}\right.$.$12-14 \mathrm{H}_{2} \mathrm{O}$ ), but the so-called $\omega$ index of the dibasic compound was somewhat lower than that of the tetrabasic compound. The crystals of $4 \mathrm{CaO}$.$\mathrm{Al}_{2} \mathrm{O}_{3} \cdot 12 \mathrm{H}_{2} \mathrm{O}$ were found to be biaxial negative, with indices $\gamma=1.542, \beta=1.538$ and $\alpha=1.522$.

The metastable invariant point for $\mathrm{C}_{2} \mathrm{AH}_{8}$ and $\mathrm{C}_{4} \mathrm{AH}_{13}$ was found to lie between 0.5 and $0.6 \mathrm{~g}$ of $\mathrm{CaO}$ per liter, and between 0.10 and $0.15 \mathrm{~g}$ of $\mathrm{Al}_{2} \mathrm{O}_{3}$ per liter. At lower lime concentrations, the 2:1 compound predominated; at higher lime concentrations the $4: 1$ compound predominated. The X-ray diffraction patterns of both prepara. tions show a hexagonal unit cell in which $a=8.8 \mathrm{~A}$. The value of $c$ for the $2: 1$ compound was $10.6 \mathrm{~A}$, and for the $4: 1$ compound was $8.2 \mathrm{~A}$. The patterns for the crystals of intermediate composition gave intensities that indicated a mixture of $\mathrm{C}_{2} \mathrm{AH}_{8}$ and $\mathrm{C}_{4} \mathrm{AH}_{13}$.

From these observations, Wells and his associates concluded that the so-called hexagonal tricalcium aluminate hydrate is in reality not a separate compound but a mixture of the hexagonal hydrated $\mathrm{C}_{2} \mathrm{~A}$ and $\mathrm{C}_{4} \mathrm{~A}$ in equal molar proportions. The similar structure of these compounds parallel to the $a$ axis led to the belief that they are capable of intercrystallization, and are made up of layers of the one compound so intimately mixed with layers of the other that the average indices of refraction are obtained.

Specimens stored in sealed vials for 2 to 3 years showed an increase in refractive indices in the low-lime compositions to values similar to those of the high-lime compositions, and the X-ray patterns in all cases were those of the $4: 1$ compound. This indicated that the $2: 1$ compound is unstable and decomposes to the $4: 1$ composition.

At temperatures above $21^{\circ} \mathrm{C}$, the hexagonal forms were found to revert rather slowly to the isometric $\mathrm{C}_{3} \mathrm{AH}_{6}$, and the solubility of the stable compound increased up to $90^{\circ} \mathrm{C}$. From observations on the formation of hydrated alumina in some preparations, it was concluded that gibbsite $\left(\mathrm{Al}_{2} \mathrm{O}_{3} \cdot 3 \mathrm{H}_{2} \mathrm{O}\right)$ is the stable phase in the system $\mathrm{CaO}-\mathrm{Al}_{2} \mathrm{O}_{3}-\mathrm{H}_{2} \mathrm{O}$ at $21^{\circ} \mathrm{C}$ up to a concentration of $0.33 \mathrm{~g}$ of $\mathrm{CaO}$ per liter, and that isometric 
$\mathrm{C}_{3} \mathrm{AH}_{6}$ is the stable phase above that concentration between $21^{\circ}$ and $90^{\circ} \mathrm{C}$. The liquid at the invariant point for $\mathrm{C}_{3} \mathrm{AH}_{6}-\mathrm{AH}_{3}$ contains $0.02 \mathrm{~g}$ of $\mathrm{Al}_{2} \mathrm{O}_{3}$ per liter at $21^{\circ} \mathrm{C}$ and $0.11 \mathrm{~g}$ of $\mathrm{Al}_{2} \mathrm{O}_{3}$ per liter at $90^{\circ} \mathrm{C}$.

It was found by Harris, Schneider, and Thorvaldson [15] that, although the isometric $\mathrm{C}_{3} \mathrm{AH}_{6}$ is the stable phase in the temperature range around $150^{\circ} \mathrm{C}$, a prolonged treatment in steam at nigher temperature results in the formation of birefringent crystalline phases. At temperatures below $200^{\circ} \mathrm{C}$, the mean refractive index of this material was 1.58. Between $205^{\circ}$ and $350^{\circ} \mathrm{C}$, rectangular prismatic plates were formed with a $\mathrm{CaO}: \mathrm{Al}_{2} \mathrm{O}_{3}$ ratio less than 1.5 , as well as $\mathrm{Ca}(\mathrm{OH})_{2}$, but no free hydrated alumina. Two of the refractive indices of the crystalline hydroaluminate were close to 1.627 .

This work indicates that, under conditions favoring hydrolysis, one and possibly two birefringent hydroaluminates may be formed: one at a temperature of about $200^{\circ} \mathrm{C}$ having a mean index of 1.58 and one at higher temperatures having an index of 1.627. It was suggested that the formation of these birefringent hydroaluminates may be an important factor in the improvement of sulfate resistance of cements subjected to steam curing.

\section{The Setting Process}

The character of the hydrated calcium silicate that was formed in systems of cement components with water was investigated by Hedin [16]. When $0.2 \mathrm{~g}$ portions of $\mathrm{C}_{3} \mathrm{~S}$ or $\beta \mathrm{C}_{2} \mathrm{~S}$ were shaken with liter quantities of water, the compounds entered the solution in the molecular proportions of the anhydrous compounds. But after about 24 hours, in the case of the $\mathrm{C}_{3} \mathrm{~S}$, a cotton-like precipitate formed having the composition CSH. In more basic solutions the reaction was different. When $500 \mathrm{ml}$ of the $\mathrm{C}_{3} \mathrm{~S}$ solution was added to 2 liters of saturated lime water, the precipitate that formed had the composition $\mathrm{C}_{2} \mathrm{SH}_{4}$. An X-ray examination showed the material to be crystalline. A number of additional experiments led Hedin to believe that this hydrate is the normal silicate compound formed during the hydration of cement.

The rate of the reaction was found to be affected greatly by the presence of other ions in the solution. Thus the reaction with either $\mathrm{C}_{3} \mathrm{~S}$ or $\mathrm{C}_{2} \mathrm{~S}$ is greatly depressed by saturated solutions of $\mathrm{Ca}$ $(\mathrm{OH})_{2}$, but to a less degree when gypsum is present with the $\mathrm{Ca}(\mathrm{OH})_{2}$. Still less depression is caused by a 5 percent solution of $\mathrm{CaCl}_{2}$ in the lime water.

On working with the calcium aluminates, Hedin found that these compounds entered into solution congruently when the concentrations were very low. As with the calcium silicates, the rate of solution was found to be greatly depressed in saturated solutions of $\mathrm{Ca}(\mathrm{OH})_{2}$, but to an even greater extent when gypsum was also present. Rapid reaction prevailed in those solutions in which quick set occurred, whereas the reactions were slow and the solubility low in solutions where the set was normal. In the latter case, the reaction appeared to be depressed due to a coating of the grains with an insoluble film of a hydration product that hindered the penetration of the solution.

Thus Hedin found that the concentration of the calcium ions in the solution affects to an important degree the solubility of both the silicate and the aluminate anhydrous compounds, but the basicity of the solution affects only the aluminates. The systematic control of these factors would permit the control of the setting process as well as many other properties that are dependent upon the character of the set. Thus gypsum accelerates the solution of the calcium silicates but retards the solution of the calcium aluminates. The $\mathrm{pH}$ may be so greatly reduced by some calcium salts, as $\mathrm{CaCl}_{2}$, that precipitation of the calcium aluminate is prevented entirely, and in its place $\mathrm{Al}(\mathrm{OH})_{3}$ may be formed. Even the composition of the hydrated calcium silicate may be changed, from $\mathrm{C}_{2} \mathrm{SH}_{4}$ in supersaturated lime solutions to $\mathrm{C}_{3} \mathrm{~S}_{2} \mathrm{H}_{x}$ in saturated lime solutions.

When quick set occurs, there is a mutual coagulation of the silicic acid and aluminum hydroxide, enclosing unhydrated grains and impairing strength. If the lime can be brought into solution rapidly, this coagulation is prevented by the prior formation of $\mathrm{C}_{4} \mathrm{~A}$ hydrate. The silicate can then hydrate unaffected by the aluminate. Gypsum would give an effect similar to the lime, due to the prior formation of insoluble calcium sulfoaluminate.

The question of set has been studied by Lerch [27], making use of a conduction calorimeter for indicating the rate and extent of heat liberation. Two or three cycles of increasing heat liberation were found for all cements. The first cycle appears rapidly after mixing with water, and is 
explained as due to the initial rapid solution of the anhydrous aluminates. During this period, lime and gypsum are going rapidly into solution and in a few minutes normally reach such a concentration that the first reactions are depressed through a sharp decrease in the solubility of the alumina in such solution. This results in a decrease in rate of heat liberation.

When the solution has become saturated with lime, the aluminates continue to dissolve slowly and react with gypsum to form calcium sulfoaluminate. The silicates dissolve and form hydrated calcium silicates. These reactions increase to the time of initial set, following which a slowing down occurs due to film formation of hydration products around unhydrated material and to the disappearance of the smaller grains. When the gypsum has become depleted, the $\mathrm{SO}_{3}$ concentration in the solution drops sharply, resulting in an accelerated solution of the aluminates and increase in heat evolution.

The rate and time of the above reactions are determined by the composition and fineness of the cements. With low $\mathrm{C}_{3} \mathrm{~A}$ and low alkali, the reaction is slow and is accelerated by gypsum. Alkalies bring about a more rapid reaction, and require a higher gypsum content for proper retardation. Thus it appeared to Lerch that each cement has a gypsum requirement for optimum retardation that is characteristic of its composition and fineness. Tests on strength, expansion in water and contraction in air all indicated that the best results are obtained when this optimum amount of gypsum is present. This optimum quantity is defined by Lerch as the minimum amount of gypsum that will give a heat-liberation curve showing two cycles of ascending and descending rates, and showing no appreciable change with larger additions of gypsum.

A convenient test for the maximum $\mathrm{SO}_{3}$ content was devised that was based on the concentration of $\mathrm{SO}_{3}$ in neat cemant pastes at 24 hours. If the pastes retain gypsum, the $\mathrm{SO}_{3}$ concentration of the extracts will approach that of saturated gypsum which is $1.2 \mathrm{~g}$ per liter. If the gypsum has been depleted, the $\mathrm{SO}_{3}$ concentration will approach that of calcium sulfoaluminate, which is about $0.05 \mathrm{~g}$ per liter. The maximum amount of gypsum permissible in the cement, according to the theory underlying the test, should be such that no or very little unreacted gypsum shall remain in the specimen of paste at 24 hours, and hence the $\mathrm{SO}_{3}$ in the extract should be of the lower order of magnitude.

Confirmation of the results of Lerch was obtained by Whittaker and Wessels [45]. They found that many cements required larger amounts of gypsum than were allowed by the standard specifications, varying between 3 and 4 percent of $\mathrm{SO}_{3}$, to retard properly the rates of hydration. By the use of the larger percentages of gypsum, little effect was noted on time of set, but improvements were observed by a reduced autoclave expansion and increased tensile and compressive strengths, especially at early ages. An increased tendency to a false set with the higher$\mathrm{SO}_{3}$ cements was noted, especially when grinding temperatures were high.

Calcium chloride was found by Lerch to accelerate the hydration of cement pastes, as indicated by an increase in heat liberated during the first few hours and a shifting of the peak of maximum heat liberation to an earlier age. This would be reflected in an earlier set and increased strength at early ages. Kalousek, Jumper, and Tregoning [24] noted that $\mathrm{CaCl}_{2}$ differed in its action from $\mathrm{CaSO}_{4}$ by bringing about in the pastes an increase in the alkalies dissolved. This was thought to accelerate the precipitation of calcium sulfoaluminate (and perhaps also of calcium chloraluminate) and so to lower the concentration of $\mathrm{CaO}$ and $\mathrm{SO}_{3}$ in the solution.

An acceleration of hydration was also found by Lerch when $\mathrm{K}_{2} \mathrm{SO}_{4}$ or $\mathrm{Na}_{2} \mathrm{SO}_{4}$ were added to the solution. This was explained as due to an interaction of the alkali sulfates with calcium hydroxide.

\section{Hydroaluminate Complex Salts}

The action of gypsum in the retardation of set, and the action of sulfate waters on concrete, can be understood only by a knowledge of the compounds and reactions in the system $\mathrm{C}_{3} \mathrm{~A}-\mathrm{CaSO}_{4}-$ $\mathrm{H}_{2} \mathrm{O}$. The formation of a calcium sulfoaluminate was known to Candlot [7] as early as 1890, and many investigators have contributed to our information. In addition to a high-sulfate form $\left(\mathrm{C}_{3} \mathrm{~A} .3 \mathrm{CaSO}_{4} .31 \mathrm{H}_{2} \mathrm{O}\right.$, which will be referred to as the "trisulfate") a low-sulfate form $\left(\mathrm{C}_{3} \mathrm{~A} \cdot \mathrm{CaSO}_{4}\right.$. $12 \mathrm{H}_{2} \mathrm{O}$ ) was discovered (referred to as the "monosulfate") [28]. The trisulfate was found to be the more stable and the only form observed in cement 
paste after reaction with sulfates. Its solubility being very low and its formation aided by the presence of $\mathrm{Ca}(\mathrm{OH})_{2}$, it formed readily in cement pastes.

The monosulfate was found by Kalousek [22] to be metastable in solutions throughout a wide range of composition, but to persist over long periods in the absence of an excess of sulfate. With increasing concentrations of alkali hydroxide in the solution, the molar ratio of $\mathrm{SO}_{3}: \mathrm{Al}_{2} \mathrm{O}_{3}$ of the crystals was found to decrease, so that the trisulfate could not exist at $\mathrm{NaOH}$ concentrations above 0.25 equivalents per liter. While the $\mathrm{SO}_{3}: \mathrm{Al}_{2} \mathrm{O}_{3}$ ratio varied between 0.68 and 0.22 , the $\mathrm{CaO}: \mathrm{Al}_{2} \mathrm{O}_{3}$ ratio remained at about 4 . These results led to the belief that a solid-solution series was formed between $\mathrm{C}_{3} \mathrm{~A} \cdot \mathrm{CaSO}_{4} \cdot 12 \mathrm{H}_{2} \mathrm{O}$ and $\mathrm{C}_{3} \mathrm{~A} \cdot \mathrm{Ca}(\mathrm{OH})_{2} \cdot 13 \mathrm{H}_{2} \mathrm{O}$, and between the tri- and monosulfate. This series could be expressed:

$$
\begin{gathered}
\mathrm{C}_{3} \mathrm{~A} \cdot 3 \mathrm{Ca}(\mathrm{OH})_{2} \cdot \mathrm{xH}_{2} \mathrm{O}-\mathrm{C}_{3} \mathrm{~A} \cdot 3 \mathrm{CaSO}_{4} \cdot 31 \mathrm{H}_{2} \mathrm{O} \\
\mathrm{C}_{3} \mathrm{~A} \cdot \mathrm{Ca}(\mathrm{OH})_{2} \cdot 13 \mathrm{H}_{2} \mathrm{O}-\mathrm{C}_{3} \mathrm{~A} \cdot \mathrm{CaSO}_{4} \cdot 12 \mathrm{H}_{2} \mathrm{O} \\
\mathrm{C}_{3} \mathrm{~A} \cdot 12 \mathrm{H}_{2} \mathrm{O}
\end{gathered}
$$

The conversion from mono- to trisulfate was found to be accompanied by an increase in volume that could explain undesirable expansions in concrete subjected to sulfate waters.

Flint and Wells [9] prepared compounds analogous to the calcium sulfoaluminates, containing $\mathrm{CaSiO}_{3}$ or $\mathrm{Ca}(\mathrm{OH})_{2}$ in place of $\mathrm{CaSO}_{4}$. The relationship between these and the corresponding sulfoaluminates may be represented as follows:

$$
\begin{gathered}
\mathrm{C}_{3} \mathrm{~A}\left\{\begin{array}{l}
\mathrm{CaSO}_{4} \\
\mathrm{CaSiO}_{3} \\
\mathrm{Ca}(\mathrm{OH})_{2}
\end{array}\right\} 12 \text { to } 13 \mathrm{H}_{2} \mathrm{O} \\
\mathrm{C}_{3} \mathrm{~A}\left\{\begin{array}{l}
3 \mathrm{CaSO}_{4} \\
3 \mathrm{CaSiO}_{3} \\
3 \mathrm{Ca}(\mathrm{OH})_{2}
\end{array}\right\} 31 \mathrm{H}_{2} \mathrm{O}
\end{gathered}
$$

It was suggested that the complex sulfoaluminates hydrate known to be formed in cement pastes might vary in composition because of partial replacement of the sulfate radical by either the hydroxyl or the silicate radical in a solid-solution series.

A noteworthy attempt to resolve the systems quantitatively has been made by Jones [21]. Examining the system $\mathrm{CaO}-\mathrm{Al}_{2} \mathrm{O}_{3}-\mathrm{CaSO}_{4}-\mathrm{H}_{2} \mathrm{O}$ at $25^{\circ} \mathrm{C}$, Jones found the trisulfate to be the only stable complex salt that was formed. The monosulfate, however, was found to be a possible metastable phase that might be formed as the end member of a solid-solution series. An abrupt increase in $\mathrm{Al}_{2} \mathrm{O}_{3}$ occurred at a $\mathrm{CaO}$ concentration of about $0.3 \mathrm{~g}$ of $\mathrm{CaO}$ per liter, and the $\mathrm{CaSO}_{4}$ concentration became very small. The solid phase then had a composition close to the monosulfate, but with increasing $\mathrm{CaO}$ concentrations the composition moved toward $\mathrm{C}_{3} \mathrm{~A} \cdot \mathrm{Ca}(\mathrm{OH})_{2}$. $12 \mathrm{H}_{2} \mathrm{O}$.

In such solutions (free of alkali and iron), Jones concludes that the complex salt first formed is the trisulfate, but that this may change over partially or completely into the metastable solid solution, to which he assigns the formula $x \mathrm{CaO} . y \mathrm{Al}_{2} \mathrm{O}_{3} . z \mathrm{CaSO}_{4}$.aq. The explanation given is that the solution becomes rapidly supersaturated with respect to $\mathrm{Ca}(\mathrm{OH})_{2}$ and, as long as solid gypsum remains, an equilibrium will be maintained between the trisultate, calcium hydroxide and gypsum. When the gypsum is used up, $\mathrm{C}_{3} \mathrm{AH}_{6}$ should form under stable equilibrium, but that compound is slow to form and the system is more likely to pass to the metastable region where the solid solution appears. In this way Jones thinks that, with a cement containing 2 percent of $\mathrm{SO}_{3}$ and 2.6 percent or more of $\mathrm{Al}_{2} \mathrm{O}_{3}$, complete conversion of the trisulfate to the solid solution is possible.

When $\mathrm{KOH}$ or $\mathrm{NaOH}$ were added to the system in amounts of 1 percent, there resulted a greatly increased solubility of alumina and a greatly decreased solubility of lime. But still the trisulfate was the only stable complex salt observed. These results differ from those of Kalousek, who found the monosulfate solid solutions to be stable above certain $\mathrm{NaOH}$ concentrations. This may be accounted for by the use, by Kalousek, of higher $\mathrm{NaOH}$ concentrations than used by Jones. Kalousek's results differed from those of Jones in that he failed to find $\mathrm{C}_{3} \mathrm{AH}_{6}$ in any of the solid phases.

\section{New Technics}

A number of new technics, resulting from the use of special equipment, have recently been applied in cement research, and merit a brief mention. 


\section{Methods of Spectrographic Analysis}

Methods have recently been developed by Helz [17] and by Helz and Scribner [18] by which eight elements may simultaneously be determined spectrographically in portland cement. These elements are sodium, potassium, lithium, magnesium, manganese, titanium, iron, and aluminum. A number of items of technic may be mentioned. The most satisfactory sample consists of a compressed pellet containing a mixture of the cement, graphite, and cobalt oxide in proper proportions. The graphite was found necessary for the smooth burning of the charge in the electrode, and the cobalt oxide is employed as the intermal standard. The disk-shaped pellet ( $1 / 2$ in. in diameter by $1 / 8 \mathrm{in}$. thick) is used as the lower electrode. A "multisource" power unit employing an overdamped condenser discharge was found to give best results.

It has been found that potassium interferes with the determination of sodium, but that the magnitude of such interference changes very little when the concentration of $\mathrm{K}_{2} \mathrm{O}$ varies between 1 and 2 percent. The difficulty was overcome by adding 0.7 percent of $\mathrm{K}_{2} \mathrm{O}$, as $\mathrm{KNO}_{3}$, to all samples and, in the calculation, reducing by that amount the $\mathrm{K}_{2} \mathrm{O}$ observed to be present.

By this procedure it was found to be possible for one operator to determine in duplicate in one day the above eight elements on 10 to 16 cements. The accuracy is probably as good as, or better than, that obtained by the usual chemical methods of analysis. The probable errors, expressed as percentages of the concentrations, are between 2 and 5 percent, except for potassium for which the error is about 8 percent.

\section{Electron Microscopy}

Another recent tool that offers possibilities of much interest in cement research is the electron microscope. By means of this instrument, micrographs may be obtained at magnifications up to 25,000 diameters with high resolution (which may subsequently be many times enlarged), and electron diffraction patterns may be photographed.

In the last few years, the instrument has been applied successfully to many problems requiring resolution of fine structure. In the field of portland cement, Eitel and his coworkers [33] have examined the hydration products of tricalcium silicate and tricalcium aluminate. More recently Katz and his associates [35] have reported the electron-micrographs of hydrated portland cements as also of some of the cement compounds. By this means Eitel found $\mathrm{C}_{3} \mathrm{~S}$ to give rise to hemispheres of $\mathrm{Ca}(\mathrm{OH})_{2}$ and nodules identified as a calcium hydrosilicate. The $\mathrm{C}_{3} \mathrm{~A}$ gave hexagonal crystals identified as $\mathrm{C}_{3} \mathrm{AH}_{12}$ and isometric crystals of $\mathrm{C}_{3} \mathrm{AH}_{6}$. Katz observed from $\mathrm{C}_{3} \mathrm{~S}$ and $\mathrm{C}_{2} \mathrm{~S}$ rhombic slabs (probably $\mathrm{CaCO}_{3}$ ) and amorphous spherulites, and from $\mathrm{C}_{3} \mathrm{~A}$ the same rhombic slabs, thin hexagonal plates and spherulites. When a sulfate was present, needles and splines of calcium sulfoaluminate were observed.

Electron micrographs of the cement compounds made by McMurdie [30] showed no evidence of the rhombic slabs observed very commonly by Katz. The $\mathrm{C}_{3} \mathrm{~A}$ yielded hexagonal plates, as did also $\mathrm{C}_{4} \mathrm{AF}$ and $\mathrm{NC}_{8} \mathrm{~A}_{3}$. The $\mathrm{C}_{3} \mathrm{~S}$ and $\mathrm{C}_{2} \mathrm{~S}$, as well as commercial cements, showed the presence of globules of gel, with fringes that suggest a possible beginning of crystallization. In the presence of gypsum, with $\mathrm{C}_{3} \mathrm{~A}$ or $\mathrm{C}_{4} \mathrm{AF}$, the heavy splines of calcium sulfoaluminate were conspicuous.

The above results are only the first pioneer work, which indicates that the electron microscope is adaptable to the examination of cement hydration products. The field of its application to the problems of cement research lies in the future. The use of electron diffraction technic has not been probed, but there is the probability that this also may be very useful. By this means the formation of solid solutions may be indicated, patterns of the several phases in a section may be separately obtained, and advantage may be taken of the opacity of thin films to electrons by applying the method to such films of hydration products formed on anhydrous crystals.

\section{X-Ray Spectrometry}

The present availability of an X-ray spectrometer (Phillips), employing a Geiger counter in place of a photographic film, makes possible the recording upon a chart both the intensity and spacings of the diffraction lines of a pattern. A photometer is not necessary for measuring the density of the lines, as intensity is indicated directly, and the spacings have only to be read from the chart.

Many advantages are possible from the use of this instrument. The examination of a specimen 
is possible in a much shorter space of time, and there are no films to be developed. The unique possibility presents itself of placing the sample in a small furnace inserted in the instrument, so that the X-ray pattern of materials at high temperatures may be determined. Such a furnace has been successfully built and operated by McMurdie and van Valkenburg [31] at the National Bureau of Standards. Its use may be of the highest importance in studies on the crystal structure of compounds, inversion temperatures and solid solutions. The field has only been indicated; its exploration lies in the future.

\section{Summary}

The foregoing may be summarized as follows: (1) The stable potash compound (or solid solution) in a cement mixture consisting of $\mathrm{K}_{2} \mathrm{O}, \mathrm{CaO}$, $\mathrm{MgO}, \mathrm{Al}_{2} \mathrm{O}_{3}, \mathrm{Fe}_{2} \mathrm{O}_{3}$, and $\mathrm{SiO}_{2}$ has the composition $\mathrm{KC}_{23} \mathrm{~S}_{12}$. When $\mathrm{SO}_{3}$ is present, the potash combines with it preferentially to form $\mathrm{K}_{2} \mathrm{SO}_{4}$. The soda of cement, in a mixture consisting of $\mathrm{Na}_{2} \mathrm{O}, \mathrm{CaO}, \mathrm{Al}_{2} \mathrm{O}_{3}$ and $\mathrm{SiO}_{2}$ may crystallize in the form of $\mathrm{NC}_{8} \mathrm{~A}_{3}$, or a solid solution of that phase in $\mathrm{C}_{3} \mathrm{~A}$; a solid solution of a soda-bearing phase in $a_{2} \mathrm{C}_{2} \mathrm{~S}$; or inclusions of a soda-bearing phase in $\beta \mathrm{C}_{2} \mathrm{~S}$. (3) The iron-bearing phase in portland cement is a solid solution of $\mathrm{C}_{2} \mathrm{~F}$ in a hypothetical $\mathrm{C}_{2} \mathrm{~A}$, which may extend beyond the composition $\mathrm{C}_{4} \mathrm{AF}$, and reach an end composition at $\mathrm{C}_{6} \mathrm{~A}_{2} \mathrm{~F}$. (4) The prismatic dark-interstitial phase of clinker is a metastable form of tricalcium aluminate possibly containing a small amount of alkali in solid solution. (5) The $\alpha-\beta$ inversion temperature of dicalcium silicate is probably $1,456^{\circ} \mathrm{C}$. (6) The $\beta-\gamma$ inversion of dicalcium silicate may be prevented by 1-mole percent additions of $\mathrm{P}_{2} \mathrm{O}_{5}, \mathrm{As}_{2} \mathrm{O}_{3}, \mathrm{~V}_{2} \mathrm{O}_{5}, \mathrm{Cr}_{2} \mathrm{O}_{3}, \mathrm{~B}_{2} \mathrm{O}_{3}$, or $\mathrm{Mn}_{2} \mathrm{O}_{3}$. (7) Tricalcium aluminate has a cubic unit cell having $a_{0}=15.24 \mathrm{~A}$ and 24 molecules. (8) $a_{2} \mathrm{C}_{2} \mathrm{~S}$ has a hexagonal symmetry, stable at a high temperature. Under proper conditions, this may be obtained at low temperature. Previously described $a_{2} \mathrm{~S}$ is $\beta \mathrm{C}_{2} \mathrm{~S}$, whose twinning is caused by the inversion and whose inclusions are the result of ex-solution of dissolved phases. (9) $\mathrm{An} \alpha^{\prime} \mathrm{C}_{2} \mathrm{~S}$ exists, having the structure of $\beta \mathrm{K}_{2} \mathrm{SO}_{4}$. It is stable between the stability range of the $a$ and the $\beta$ forms. (10) Hexagonal $\mathrm{C}_{3} \mathrm{~A}$-hydrate does not exist. The material previously designated as such is a mix- ture of $\mathrm{C}_{2} \mathrm{~A}$ aq and $\mathrm{C}_{4} \mathrm{~A}$ aq. (11) In steam at temperatures above $200^{\circ} \mathrm{C}$, the isometric $\mathrm{C}_{3} \mathrm{AH}_{6}$ is changed into birefringent phases of two forms. (12) Supporting evidence is given in favor of the film theory to account for the reactions of set. (13) Each cement has a gypsum requirement for optimum retardation that is characteristic of the cement. (14) Calcium sulfoaluminate forms a series of solid solutions of high and low sulfate content, and the sulfate may be progressively replaced by hydroxyl or silicate. (15) Spectroscopic methods are developed by which 8 elements may be determined in duplicate on 10 to 16 cements by one operator in one day. (16) Methods of electron microscopy and X-ray spectrometry show promise of useful application in cement research.

\section{References}

[1] R. H. Bogue, The chemistry of portland cement (Reinhold Publishing Co., New York, N. Y., 1947).

[2] E. B. Bradenberger, Symposium on the chemistry of cements, p. 122 (Stockholm, 1938).

[3] M. A. Bredig, J. Phys. Chem. 46, 474, 801 (1942); 47, 587 (1943); 49, 537 (1945); Am. Mineralogist 28, 594 (1943)

[4] L. S. Brown. Unpublished data.

[5] L. T. Brownmiller, Am. J. Sci. 29, 260 (1935); PCAF Paper 30; Am. J. Sci. 35, 24 (1938) ; PCAF Paper 35.

[6] L. T. Brownmiller, R. H. Bogue, BS J. Research 8, 289 (1932) RP414; Am. J. Sci. 23, 501 (1932); PCAF Paper 25.

[7] E. Candlot, Bull. soc. encour. ind. nat., p. 682 (1890).

[8] L. A. Dahl, J. Phys. Chem. 50, 96 (1946).

[9] E. P. Flint and L. S. Wells, J. Research NBS 33, 471 (1944) RP1623.

[10] K. T. Greene, J. Research NBS 32, 1 (1944) RP1570; PCAF Paper 45.

[11] K. T. Greene and R. H. Bogue J. Research NBS 36, 185 (1946) RP1699; PCAF Paper 47.

[12] W. C. Hansen and R. H. Bogue, Ind. Eng. Chem. 19, 1260 (1927); PCAF Paper 10.

[13] W. C. Hansen, L. T. Brownmiller, and R. H. Bogue, J. Am. Chem. Soc. 50, 396 (1928); PCAF Paper 13.

[14] E. A. Harrington, Am. J. Sci. 13, 467 (1927); PCAF Paper 8

[15] G. M. Harris, W. G. Schneider, and T. Thorvaldson, Can. J. Research 21, 65 (1943).

[16] R. Hedin, Proc. Swedish Cement Concrete Inst. 3 (1945).

[17] A. W. Helz, J. Research NBS 24, 129 (1945) RP1633; PCAF Paper 46.

[18] A. W. Helz and B. F. Scribner, J. Research NBS 38, 439 (1947) RP1786.

[19] H. Insley, E. P. Flint, E. S. Newman, and J. A. Swenson, J. Research NBS 21, 355 (1938) RP1135.

[20] H. Insley and H. F. MeMurdie, J. Research NBS 20 , 173 (1938) RP1074. 
21] F. E. Jones, Trans. Faraday Soc. 35, 1484 (1939); J. Phys. Chem. 48, 311, 356, 379 (1944); 49, 344 (1945).

[22] G. L. Kalousek, Univ. of Maryland Dissertation (1941); J. Am. Concrete Inst. 37, 692 (1941) J. Phys. Chem. 49, 405 (1945).

[23] G. L. Kalousek, C. H. Jumper, and J. J. Tregoning, Rock Products (April 1941).

[24] G. L. Kalousek, C. H. Jumper, and J. J. Tregoning, J. Research NBS, 30, 215 (1943) RP1530.

[25] K. Lagerquist, S. Wallmark, and A. Westgren, Z. Anorg. allgem. Chem., 234, 1 (1937).

[26] F. M. Lea and T. W. Parker, Phil. Trans. Royal Soc., 234, No. 731, [A] 1 (1934).

[27] W. Lerch, Proc. Am. Soc. Testing Materials, 46, (1946). In press.

[28] W. Lerch, F. W. Ashton, and R. H. Bogue, BS J. Research 2, 715 (1929) RP54; PCAF Paper 19.

[29] H. F. McMurdie, J. Research, NBS 27, 499 (1941), RP1437.

[30] H. F. MeMurdie. Unpublished data.

[31] H. F. McMurdie and A. van Valkenburg. In preparation.

[32] E. S. Newman and L. S. Wells, J. Research NBS 36, 137 (1946), RP1696.

[33] O. E. Radezewski, H. O. Muller, and W. Eitel, Naturwiss., $27,807,837$ (1939).
[34] G. Rankin and F. E. Wright, Am. J. Sci., 29, 1 (1915).

[35] C. M. Sliepoevich, L. Gildart, and D. M. Katz, Ind. Eng. Chem. 35, 1178 (1943).

[36] T. E. Stanton, Proc. Am. Soc. Civil Eng. 66, 1781 (1940).

[37] F. A. Steele and W. P. Davey, J. Am. Chem. Soc. 51, 2283 (1929).

[38] M. A. Swayze, Am. J. Sci. 244, 1; 65 (1946).

[39] W. C. Taylor, J. Research NBS 21, 315 (1938), RP1131; PCAF paper 37.

[40] W. C. Taylor, J. Research NBS 27,311 (1941), RP1421; PCAF Paper 40.

[41] W. C. Taylor, J. Research NBS 29, 437 (1942), RP1521. PCAF Paper 43.

[42] W. C. Taylor, J. Research NBS 30, 329 (1943), RP1536; PCAF Paper 44.

[43] G. W. Ward, J. Research NBS 26, 49 (1941), RP1358; PCAF Paper 39.

[44] L. S. Wells, W. F. Clarke, and H. F. McMurdie, J. Research NBS 30, 367 (1943), RP1539.

[45] A. G. Whittaker and V. E. Wessels, Rock Products, p. 95 (Aug. 1945).

[46] S. Zerfoss and H. M. Davis, J. Am. Ceramic Soc., 26, 302 (1943).

Washington, March 24, 1947. 